\title{
Bacterial infections of the equine genital tract
}

Wittenbrink, Max M

\begin{abstract}
Bacterial infections of the genitial tract are the major cause of reproductive failure in the mare. The variety of bacteria involved has been carefully established in the past and is approved in recent studies. There are approved laboratory procedures for etiologic diagnostics of bacterial infections of the female equine genital tract. Innovative molecular based approaches aim at elucidating, for instance, potential transmission modes of opportunistic pathogens like Pseudomonas aeruginosa, or at analysing genital microbial communities (microbiomes). The latter approach may provide new and more dynamic insights into the pathogenesis of genital infections since alteration of microbiomes is known to be associated with several pathogenic conditions.
\end{abstract}

DOI: https://doi.org/10.21836/PEM20120107

Other titles: Bakterielle Infektionen des Genitaltraktes bei Pferden

Posted at the Zurich Open Repository and Archive, University of Zurich ZORA URL: https://doi.org/10.5167/uzh-61077

Journal Article

Published Version

Originally published at:

Wittenbrink, Max M (2012). Bacterial infections of the equine genital tract. Pferdeheilkunde, 28(1):3032.

DOI: https://doi.org/10.21836/PEM20120107 


\title{
Bacterial infections of the equine genital tract
}

\author{
Max M. Wittenbrink
}

Institute of Veterinary Bacteriology, Vetsuisse-Faculty, University of Zurich, Zurich, Switzerland

\begin{abstract}
Summary
Bacterial infections of the genitial tract are the major cause of reproductive failure in the mare. The variety of bacteria involved has been carefully established in the past and is approved in recent studies. There are approved laboratory procedures for etiologic diagnostics of bacterial infections of the female equine genital tract. Innovative molecular based approaches aim at elucidating, for instance, potential transmission modes of opportunistic pathogens like Pseudomonas aeruginosa, or at analysing genital microbial communities (microbiomes). The latter approach may provide new and more dynamic insights into the pathogenesis of genital infections since alteration of microbiomes is known to be associated with several pathogenic conditions.
\end{abstract}

Keywords: mare, genital infection, bacteria, microbiomes, reproduction

\section{Bakterielle Infektionen des Genitaltraktes bei Pferden}

Bakterielle Infektionen des Genitaltraktes sind eine wichtige Ursache von Fruchtbarkeitsstörungen bei der Stute. Das über Jahre ermittelte Spektrum der ursächlich beteiligten Bakterien ist weiterhin beständig. Es handelt sich um opportunistische Erreger, die mit konventionellen bakteriologischen Verfahren zuverlässig nachweisbar sind. Parallel zur bewährten klinisch ausgerichteten Labordiagnostik der Genitalinfektionen befassen sich neve Forschungsansätze mit grundsätzlichen Fragen der Mikrobiologie des Genitaltraktes. So können molekularbiologische Analysen durchaus neue Aspekte etwa zum Übertragungsmodus von opportunistischen Genitaltraktinfektionserregern wie Pseudomonas aeruginosa aufzeigen und die molekularbiologische Analyse komplexer mikrobieller Lebensgemeinschaften (sog. Mikrobiome) etwa im Genitaltrakt wird grundlegende Einblicke in die Dynamik solcher Lebensgmeinschaften etwa im Verlauf pathogener Prozesse ermöglichen.

Schlüsselwörter: Stute, Genitalinfektion, Bakterien, Molekularbiologie, Mikrobiome, Reproduktion

Genital tract infections leading to pathogenic conditions occur in mares and in stallions. Being the major cause of reduced fertility in mares, bacterial infections of the female genital tract are of extraordinary clinical significance. Bacteria involved in equine endometritis are for the most part considered to be opportunistic pathogens. They are capable of colonizing the lower genital tract as well as a variety of extragenital locations in the horse; yet they are usually barred from ascending the cervix and uterus by host defences, in particular by protective impacts of the endogenous vaginal flora and local activities of the innate and acquired immune system. The pivotal factor in the pathogenesis of bacterial equine endometritis is the uterine clearance ability. This term is used to subsume all host factors which may exert significant influence on the clinical outcome of a uterine bacterial infection (LeBlanc and Causey 2009, Lu and Morresey 2006).

Most of the microbiological studies on the mare's genital tract are carried out as a 'snapshot' in time thus giving the impression that the indigenous flora is static and consists of a manageable number of taxons. Traditional culture-based analyses cannot map the true composition of the genital flora. They are restricted to allocate a limited number of colonies as members belonging to a broad phenotypic or phylogenetic branch (Lamont et al. 2011 , Rota et al. 2011). This clinically targeting 'traditional' approach was in fact successfully applied to identify a variety of bacteria, e.g. Streptococcus equi subspecies zooepidemicus capable of inducing genital infection. However, culture-dependent approaches cannot render valid assessments on the diversity and the dynamics within the genital microbial communities. First studies on the human vaginal microbiome (the collective genome of the genital microorganisms) show that traditional culture-dependent approaches cover only $20 \%$ of the actual bacterial taxons. Not accounted for is the fact that genital microbial communities undergo shifts in their representation, abundance and virulence over time, and that they are affected by many influences (Lamont et al. 2011 ). From first results on the genital human microbiome we can derive that the microbial flora of the female equine genital tract is certainly far more complex than assumed. Individual confirmations of fastidious bacteria such as Eremococcus coleocola in the equine genital tract support the fact that our present-day knowledge on the equine genital flora is limited indeed to the bacteria easily accessible in clinical bacteriology. (Collins et al. 1999, Rota et al. 2011 ). A detailed analysis of the equine genital microbiome may enhance our understanding of the normal composition of the genital flora as well as dysbiotic shifts during the pathogenesis of bacterial endometritis. However, applying molecular technical advancements remains an issue to be valued carefully in the light of today's limitations of cultureindependent techniques (Forney et al. 2004, Kalra et al. 2007).

As outlined above, there is a limited number of initial bacteria concerned in equine endometritis. Even recent studies on the spectrum of genitopathogenic bacteria in the mare coincide with the broad experience gained over decades, i.e. the equine endometritis is in most cases caused by a rather small variety of bacterial species (Albihn et al. 2003, Møller Nielsen 2005). Streptococcal infections, in particular uterine infections with Streptococcus equi ssp. zooepidemicus have long 
been established as the leading cause of bacteria-induced endometritis in the mare.

The genus Streptococcus (S.) combines gram positive mainly anaerobic but aerotolerant cocci with an average diameter of 0,5 bis $2,0 \mu \mathrm{m}$. The species $\mathrm{S}$. equi comprises two subspecies (ssp.): ssp. zooepidemicus (further referred to as SEZ) and ssp. equi (SEE). The species S. equi, S. equisimilis and S. dysgalactiae pertain to the Lancefield serogroup C. SEZ is regarded as the archetypal species of the closely related SEE (Chanter et al. 1997, Harrington et al. 2002, Timoney 2004).

At a rate of up to $50 \%$ of the endometritis cases SEZ is globally the most considerable bacterial endometritis agent in mares (Albihn et al. 2003, Causey 2006). The wide prevalence of inapparent genital and extragenital infections with SEZ in the horse points to a close adaption of this pyogenic bacterium to the horse. In diagnostics of bacterial endometritis - particularly in SEZ tests - cultures on blood agar are the acknowledged standard. SEZ are identifiable based on their haemolytic reaction, group carbon antigen $C$ and phenotypic tests (Facklam 2002). Molecular methods such as the DNA fingerprinting using different restriction enzymes of the bacterial DNA are useful for an epidemiologically relevant typing of SEZ. Recent interesting sequences aimed at identifying streptococcal species and subspecies are the sodA gene encoding a superoxide dismutase and the chaperonin encoding gene groEL of both, SEE and SEZ (Alber et al. 2004, Glazunova et al. 2009). Even the rather well known gene encoding the $M$-like proteins of SEZ is suitable to establish genetic differentiation of SEZ, and genetic analyses have shown that horses may be infected simultaneously with a number of different SEZ types (Timoney et al. 1991, Timooney 2004).

The pathogenesis of SEZ-induced endometritis bases on interactions between bacterial virulence factors and the infected host tissues. SEZ composes a non-antigen anti-phagocytic hyaluronic acid capsule tested relevant mainly in SEE. Nevertheless, based on the close relationship amongst both subspecies it is an indicative virulence factor for SEZ too. Yet another virulence factor of SEZ are M-protein-like surface proteins capable of depriving the bacterium of unspecific and specific immune reactions caused by attaching to the Fcregion of $\lg G$ and $\lg A$. The $M$-like proteins also bind fibrinogen (Timoney et al. 1997). Streptococci binding fibrinogen to the M-like protein attach to phagocytes too, yet they are not internalized. Even SEZ strains are able to resist complementmediated cell lysis which might be mediated by the M-like protein (Causey et al. 1995). The antigenicity of the M-like protein of SEE is mainly responsible for the mounting of a protective immune response. The entire SEE genome is highly preserved and even isolates from different continents do not vary. By contrast, SEZ shows a high genetic and antigenic variability particularly with the homologue of the SEE M-like protein gene (Timoney et al. 1991). Timoney and Guan (1996) characterized opsophagocytic and protective epitopes of a SEE M-like protein using monoclonal antigen. They found yet another SEE M-like protein (SzPSe) very similar to the M-like protein (SzP) of SEZ, however without the ability to build cross protective antibodies against SEE (Timoney et al. 1995). The heterogeneity of the SEZ M-like proteins obviously is due to homologous recombination between intragenic repeats. The vast variability of the $M$-like protein of SEZ is mainly responsible for the fact that a protective cross immunity cannot be mounted (Causey 2006). One major function of the M-like protein surface structure of SEZ could be the binding of so-called $\alpha 2$ macroglobulines which are physiologically released by host tissues as a protective measure against proteases released by phagocytic cells. This protective ability of $\alpha 2$ macroglobulines may pass on to bacteria such as SEZ after binding to the bacterial surface. Generally, the characteristics of SEZ outlined here help the bacteria to successfully establish itself in the genital tract and to induce inflammation.

Other relevant bacteria are members of the Enterobacteriaceae, namely Escherichia (E.) coli, Klebsiella species of different capsule types, Proteus, and Enterobacter. By default of other more valid criteria the etiologic relevance of $E$. coli is so far mainly deduced from in vitro hemolytic growth on blood agar as an indicator for cell-damaging extracellular bioactive bacterial products. Recently, Albihn et al. (2003) described a significant correlation between the detection of E. coli in uterine swabs, and a symptomless repeat breeding in mares. In conclusion, a characterization of uterine $\mathrm{E}$. coli isolates for virulence factors which may be involved in the induction of endometrial inflammation seems adequate (Chen et al. 2003). In this context it is of particular interest to note that only a low percentage of uterine $E$. coli isolates exhibited hemolytic growth (Albihn et al. 2003).

The vast group of nonfermenters is dominated by Pseudomonas (P.) aeruginosa which is an opportunistic bacterium with a broad variety of pathogenic attributes causing infection (known mainly due to its relevance in human medicine). Aside venereal transmission from the penile microflora of stallions other modes of transmission or infection from environmental sources must be considered too (Kidd et al. 2011). The bacterium attaches to and colonizes mucous membranes and produces endometritis. This process is promoted by pili, extracellular enzymes and toxins. Many strains of P. aeruginosa produce exotoxin $A$ which causes tissue necrosis due to blocking protein synthesis of host cells. P. aeruginosa and other pseudomonads are resistant to many antimicrobial agents and are, therefore, often difficult to control. Pseudomonads and other bacteria survive in nature by forming biofilms on surfaces. A biofilm is a structured consortium of bacteria embedded in a self-produced polymer matrix consisting of polysaccharide, protein and extracellular DNA. Bacterial biofilms are resistant to antibiotics, disinfectant chemicals and to phagocytosis and other components of the innate and adaptive inflammatory defense system of the body. It is known, for example, that in bacterial vaginosis in women the most significant bacteria Gardnerella vaginalis grow in the form of biofilms (Braga et al. 2010). However, the impact of biofilms on endometrial inflammation is not yet well understood despite valid indications that the formation of biofilms might play a role in the pathogenesis of the equine endometritis. (LeBlanc 2010). Yet to-date the presence of bacterial biofilms on the endometrial mucosa of mares suffering from endometeritis could not be confirmed directly.

Another bacterial agent of global concern in equine infectious endometritis is Taylorella (T.) equigenitalis. This bacterium is closely adapted to the specific environmental conditions of the equine genital tract, whereby it is the only venere- 
al transmissible bacterial agent in horses (Samper and Tibary 2006). Recently, a phylogenetically close relative of T. equigentialis, i.e. T. asinigenitalis has been isolated from the genital tract of male donkeys (Jang et al. 2001). Under natural conditions T. asinigenitalis is apparently able to colonize also the equine male genital tract. It is thus important to analyse whether this bacterial species is genitopathogenic in the mare too (Båverud et al. 2006).

Although often the bacterial equine endometritis bases on monoinfection we must consider that mixed infections do occur. Mixed infections however - in particular those with gram negative fastidious anaerobes such as Bacteroides species - but also infections with fastidious bacteria such as mycoplasmas or even chlamydiae cannot be detected by bacteriological standard tests.

In conclusion, the spectrum of genitopathogen bacteria in the horse is clearly arranged. Yet there are many complicated cases of endometritis which are hard to treat. Here we often find combinations of diverse deficiencies in the mares concerned such as, for instance, anatomic deviations supporting chronic pathological colonisations of the genital tract, and polybacterial infections of the uterus. Such cases demand for a critical bacteriologic baseline study, inclusive of an antibiotics sensitivity test of the bacteria involved. In view of the emergency of antibiotics resistant bacteria, even in equine medicine no one should forgo antibiotic sensitivity testing of bacteria isolates from genital infections in the horse.

\section{References}

Alber J., El-Sayed A., Estoepangestie S., Lämmler C. and Zschöck M. (2004) Dissemination of the superantigen encoding genes seeL, seeM, szeL and szeM in Streptococcus equi subsp. equi and Streptococcus equi subsp. zooepidemicus. Vet. Microbiol. 109, 135-141

Albihn A., Båverud V. and Magnusson U. (2003) Uterine microbiology and antimicrobial susceptibility in isolated bacteria from mares with fertility problems. Acta vet. scand. 44, 121-129

Båverud V, Nyström C. and Johansson K. E. (2006) Isolation and identification of Taylorella asinigenitalis from the genital tract of a stallion, fist case of a natural infection. Vet. Microbiol. 116, 294-300

Braga P. C., Dal Sasso M., Culici M. and Spallino A. (2010) Inhibitory activity of thymol on native and mature Gardnerella vaginalis biofilms: in vitro study. Arzneimittelforschung 60, 675-681

Causey R. C., Paccamonti D. L. and Todd W. J. (1995) Antiphagocytic properties of uterine isolates of Streptococcus zooepidemicus and mechanisms of killing in freshly obtained blood of horses. Am. J. Vet. Res. 56, 321-328

Causey R. C. (2006) Making sense of equine unterine infections: the many faces of physiological clearance. Vet. J. 172, 405-421

Chanter N., Collin N., Holmes N., Binns M. and Mumford J. (1997) Characterization of the Lancefield group C Streptococcus 16S rRNA intergenic spacer and its potential for identification and subspecies typing. Epidemiol. Infect. 1 18, 125-135

Chen Y. M. M., Wrigth P. J., Lee C. S. and Browning G. F. (2003) Uropathogenic virulence factors in isolates of Escherichia coli from clinical cases of canine pyometra and feces of healthy bitches. Vet Microbiol. 94, 57-69

Collins M. D., Rodriguez Jovita M.,. Lawson P. A, Falsen E. and Foster $G$. (1999) Characterization of a novel gram-positive, catalasenegative coccus from horses: description of Eremococcus coleocola gen. nov., sp. nov. Int. J. Syst. Bacteriol. 4, 1381-1385

Facklam R. (2002) What happened to the streptococci: overview of taxonomic and nomenclature changes. Clin. Microbiol. Rev. 15, $613-630$
Forney L. J., Zhou X. and Brown C. J. (2004) Molecular microbial ecology: land of the one-eyed king. Curr. Opin. Microbiol. 7, 210-220

Glazunova O. O., Raoult D. and Roux V. (2009) Partial sequence comparison of the $r p o B$, sodA, groEL and gyrB genes within the genus Streptococcus. Int. J. Syst. Evolut. Microbiol. 59, 2317. 2322

Harrington D. J., Sutcliffe I. C. and Chanter N. (2002) The molecular basis of Streptococcus equi infection and disease. Microb. Infect. 4, 501-510

Jang S. S., Donahue J. M., Arata A. B., Goris J., Hansen L. M., Earley D. L., Vandamme P. A. R., PTimoney. J. and Hirsh D. C. (2001) Taylorella asinigenitalis sp. nov., a bacterium isolated from the genital tract of male donkeys (Equus asinus). Int. J. Syst. Evolut. Microbiol. 51, 971-976

Kalra A., Palcu C. T., Sobel J. D. and Akins R. A. (2007) Bacterial vaginosis: culture- and PCR-based characterizations of a complex polymicrobial disease's pathobiology. Curr. Infect. Dis. Rep. 9, 485-500

Kidd T. J., Gibson J. S., Moss S., Greer R. M., Cobbold R. N., Wright J. D., Ramsay K. A., Grimwood K. and Bell S. C. (2011) Clonal complex Pseudomonas aeruginosa in horses. Vet. Microbiol. 149, 508-512

Lamont R. F., Sobel J. D., Akins R. A., HassanS. S., Chaiworapongsa T., Kusanovic J. P. and Romero R. (2011) The vaginal microbiome: new information about genital tract flora using molecular based techniques. BJOG. 118,533-549

LeBlanc M. M. and Causey R. C. (2009) Clinical and subclinical endometritis in the mare: both threats to fertility. Reprod. Dom. Anim. 44, 10-22

LeBlanc M. M. (2010) Advances in the diagnosis and treatment of chronic infectious and post-mating-induced endometritis in the mare. Reprod. Domest. Anim. 45, $21-27$

Lu K. G. and Morresey P. R. (2006) Reproductive tract infections in horses. Vet. Clin. Equine 22, 519-552

Møller Nielsen J. (2005) Endometritis in the mare: a diagnostic study comparing cultures from swab and biopsy. Theriogenology 64, $510-518$

Rota A., Calicchio E., Nardoni S., Fratini F., Ebani V. V., Sgorbini M., Panzani D., Camillo F. and Mancianti F. (2011) Presence and distribution of fungi and bacteria in the reproductive tract of healthy stallions. Theriogenology 76, 464-470

Samper J. C. and Tibary A. (2006) Disease transmission in horses. Theriogenology 66, 551-559

Timoney J. F. (2004) The pathogenic equine streptococci. Vet. Res. 35, 397-409

Timoney J. F. and Guan M. (1996) Characterisation of murine monoclonal antibodies recognising opsonic, mouse-protective, chaining and mucosally relevant epitopes on the $M$ protein of Streptococcus equi subspecies equi. Res. Vet. Sci. 60, 76-81

Timoney J. F., Bryans J. T., Galan J. and Ding J. (1991) M proteins of the equine group $C$ streptococci. In: Dunny, G. M. et al.: Genetics and molecular biology of streptococci, lactococci, and enterococci. Amer. Soc. Microbiol., Washington DC, USA, 1991, 160 164

Timoney J. F., Walker J., Zhou M. and Ding J. (1995) Cloning and sequence analysis of a protective $M$-like protein gene from Streptococcus equi subsp. zooepidemicus. Infect. Immun. 63, 14401445

Timoney J. F., Artiushin S. C. and Boschwitz J. S. (1997) Comparison of the sequences and functions of Streptococcus equi M-like proteins SeM and SzPSe. Infect. Immun. 65, 3600-3605

Prof. Max M. Wittenbrink

Institute of Veterinary Bacteriology

Vetsuisse-Faculty, University of Zurich

Winterthurerstrasse 270

8057 Zurich

Switzerland

wittenbr@vetbakt.uzh.ch 